University of Tennessee Health Science Center

UTHSC Digital Commons

\title{
Silver Doped Hydroxyapatite Coating on Titanium Surfaces and its Effect on Early Bone Response and Osseointegration
}

Nicole Besu

University of Tennessee Health Science Center

Follow this and additional works at: https://dc.uthsc.edu/dissertations

Part of the Periodontics and Periodontology Commons

\section{Recommended Citation}

Besu, Nicole, "Silver Doped Hydroxyapatite Coating on Titanium Surfaces and its Effect on Early Bone Response and Osseointegration" (2007). Theses and Dissertations (ETD). Paper 24. http://dx.doi.org/ 10.21007/etd.cghs.2007.0027.

This Thesis is brought to you for free and open access by the College of Graduate Health Sciences at UTHSC Digital Commons. It has been accepted for inclusion in Theses and Dissertations (ETD) by an authorized administrator of UTHSC Digital Commons. For more information, please contact jwelch30@uthsc.edu. 


\title{
Silver Doped Hydroxyapatite Coating on Titanium Surfaces and its Effect on Early Bone Response and Osseointegration
}

\begin{abstract}
The clinical success of dental implants is determined mostly by surface properties of implants and interactions with surrounding tissues. Furthermore, clinical success of dental implants is directed by implant surfaces and bone cell responses that promote osseointegration and long-term stability. Hydroxyapatite (HA)-coated Titanium (Ti) implants have been widely used due to its effect on bone response. However, microbial infection is common. One material known to have anti-microbial properties is silver (Ag). However, the effects $\mathrm{Ag}$ has on osteoblastic activity as well as decrease bacterial load has yet to be determined.

In this study, the effect of Ag-doped HA coatings on initial bacterial adhesion and osteoblast cell proliferation, differentiation, and mineralization was investigated. Using a sol-gel process, HA coatings doped with $2 \mathrm{wt} \%$ AgNO3 were prepared. Coated surfaces were characterized using Xray diffraction (XRD). The osteoblast cell attachment, differentiation which is measured by alkaline phosphatase activity, and mineralization which is measured by osteocalcin activity were evaluated using human embryonic palatal mesenchyme cells (HEPM), an osteoblast precursor cell line. Initial bacteria adhesion was evaluated using an RP12 strain of Staphylococcus epidermidis (ATCC 35984) and the Cowan I strain of Staphylococcus aureus.
\end{abstract}

A significant difference in osteoblastic cell attachment over time was observed with $2 \% \mathrm{Ag}$-doped $\mathrm{HA}$ having the least cell attachment. The use of HEPM cells indicated no significant difference in alkaline phosphatase specific activity or osteocalcin activity among the $2 \%$ Ag-doped HA, HA, and Ti surfaces. Furthermore, the in vitro bacterial adhesion study indicated a significantly reduced number of $S$. epidermidis and S. aureus on Ag-doped HA surfaces when compared to HA and Ti surfaces.

Overall, it was concluded that $2 \%$ Ag-doped HA surfaces have similar osteoconductive activity when compared to HA and Ti surfaces. It was also concluded that the doping of HA with Ag minimized the adhesion of bacteria on its surface. Further studies on Ag-doped HA surfaces should involve long and short-term animal studies to evaluate its biocompatibility and ability to induce bone formation for implant stability, as well as bacterial adhesion properties. Furthermore, a decreased concentration of Ag may aid in an increasing osteogenic activity as well as have an antimicrobial effect.

\section{Document Type}

Thesis

Degree Name

Master of Dental Science (MDS)

Program

Periodontology

Research Advisor

Joo L. Ong, Ph.D.

\section{Keywords}

silver, hydroxyapatite, silver doped hydroxyapatite, titanium, osseointegration, bacterial attachment 


\section{Subject Categories}

Dentistry | Medicine and Health Sciences | Periodontics and Periodontology 
SILVER DOPED HYDROXYAPATITE COATING ON TITANIUM SURFACES AND ITS EFFECT ON EARLY BONE RESPONSE AND OSSEOINTEGRATION

\author{
A Thesis \\ Presented for \\ The Graduate Studies Council \\ The University of Tennessee \\ Health Science Center
}

\author{
In Partial Fulfillment \\ Of the Requirements for the Degree \\ Master of Dental Science \\ From The University of Tennessee
}

By

Nicole Besu

May 2007 


\section{ACKNOWLEDGEMENTS}

I would like to thank everyone who has helped me in my process and journey of becoming a periodontist. I would especially like to thank Dr. Ong. Without his hard work and knowledge this thesis would not have been possible. I would like to thank Dr. Fry who has devoted his time and energy to the students and the specialty. I would also like to thank the entire faculty who has shared their time and knowledge to train and develop my specialty skills. Lastly, I must thank my family and friends, for without their guidance, love and support I would not have been able to accomplish all my merits. 


\begin{abstract}
The clinical success of dental implants is determined mostly by surface properties of implants and interactions with surrounding tissues. Furthermore, clinical success of dental implants is directed by implant surfaces and bone cell responses that promote osseointegration and long-term stability. Hydroxyapatite (HA)-coated Titanium (Ti) implants have been widely used due to its effect on bone response. However, microbial infection is common. One material known to have anti-microbial properties is silver (Ag). However, the effects $\mathrm{Ag}$ has on osteoblastic activity as well as decrease bacterial load has yet to be determined.

In this study, the effect of Ag-doped HA coatings on initial bacterial adhesion and osteoblast cell proliferation, differentiation, and mineralization was investigated. Using a sol-gel process, HA coatings doped with 2 wt \% AgNO3 were prepared. Coated surfaces were characterized using Xray diffraction (XRD). The osteoblast cell attachment, differentiation which is measured by alkaline phosphatase activity, and mineralization which is measured by osteocalcin activity were evaluated using human embryonic palatal mesenchyme cells (HEPM), an osteoblast precursor cell line. Initial bacteria adhesion was evaluated using an RP12 strain of Staphylococcus epidermidis (ATCC 35984) and the Cowan I strain of Staphylococcus aureus.
\end{abstract}

A significant difference in osteoblastic cell attachment over time was observed with $2 \%$ Ag-doped HA having the least cell attachment. The use of HEPM cells indicated no significant difference in alkaline phosphatase specific activity or osteocalcin activity among the $2 \%$ Ag-doped HA, HA, and Ti surfaces. Furthermore, the in vitro 
bacterial adhesion study indicated a significantly reduced number of S. epidermidis and S. aureus on Ag-doped HA surfaces when compared to HA and Ti surfaces.

Overall, it was concluded that 2\% Ag-doped HA surfaces have similar osteoconductive activity when compared to HA and Ti surfaces. It was also concluded that the doping of HA with Ag minimized the adhesion of bacteria on its surface. Further studies on Ag-doped HA surfaces should involve long and short-term animal studies to evaluate its biocompatibility and ability to induce bone formation for implant stability, as well as bacterial adhesion properties. Furthermore, a decreased concentration of Ag may aid in an increasing osteogenic activity as well as have an antimicrobial effect. 


\section{TABLE OF CONTENTS}

CHAPTER 1. INTRODUCTION ...................................................

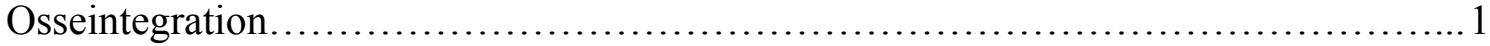

Titanium........................................................................ 1

Hydroxyapatite............................................................... 2

Hydroxyapatite and Titanium......................................................

Limitations......................................................................

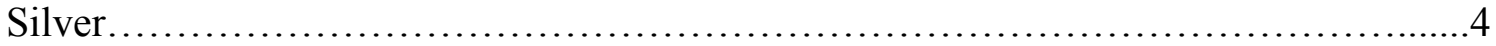

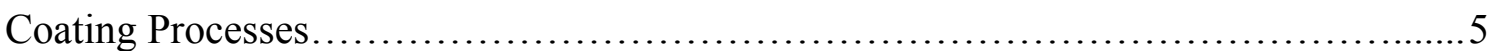

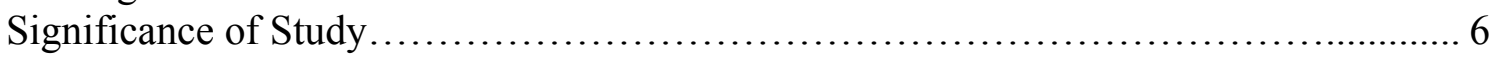

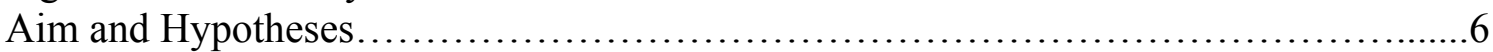

CHAPTER 2. METHODOLOGY ............................................. 8

Titanium Substrates............................................................

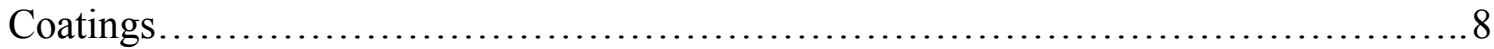

Materials Characterization....................................................... 9

Osteoblast Cell Culture Study................................................... 9

Cell Attachment .................................................... 10

Alkaline Phosphatase Specific Activity................................. 11

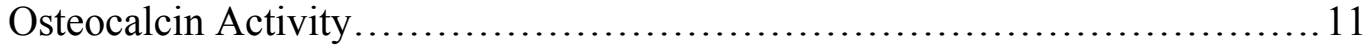

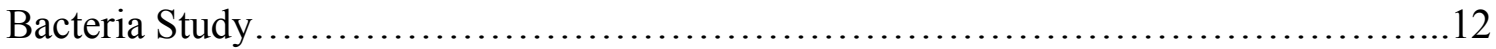

CHAPTER 3. RESULTS .................................................... 14

Materials Characterization................................................... 14

Cell Attachment................................................................... 14

Alkaline Phosphatase Specific Activity............................................ 15

Osteocalcin Activity ......................................................... 15

Bacteria Study.......................................................... 17

CHAPTER 4. DISCUSSION ...................................................... 19

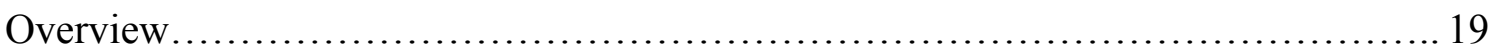

Future Research......................................................... 21

Conclusion................................................................ 21

LIST OF REFERENCES.................................................. 23

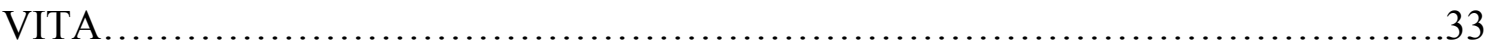




\section{LIST OF FIGURES}

Figure 1. Characteristic x-ray diffraction pattern of (a) HA and (b) AgHA coatings, confirming the crystallinity of HA formed on the surfaces......14

Figure 2. Osteoblastic cell attachment to different surfaces................... 15

Figure 3. Alkaline phosphatase activity on different surfaces................... 16

Figure 4. Osteocalcin activity on different surfaces.........................

Figure 5. Attachment of S. aureus to different surfaces....................... 17

Figure 6. Attachment of S. epidermidis to different surfaces.................... 18 


\section{CHAPTER 1. INTRODUCTION}

\section{Osseointegration}

The clinical success of dental implants is partly dictated by the surface properties of the implants and their interaction with the host. Furthermore, the clinical success of dental implants is directed by implant surfaces and bone cell responses that promote rapid osseointegration and long-term stability. Selecting materials based on their biocompatibility is an important matter when used for medical devices and dental implants. Adding materials to the surface may modify and affect early onset of osseointegration and bone cell attachment. Osseointegration is defined as a "direct structural and functional connection between ordered, living bone and the surface of a load-carrying implant". When osseointegration occurs, the nonbiologic material is in direct contact with bone, and no rejection or inflammatory response is evident.

\section{Titanium}

An example of a material that is frequently used is titanium (Ti), due to its biocompatible nature. Ti has the ability to resist corrosion in aggressive body fluids due to the stable oxide layer of about 3-5nm thick. Ti's oxide layer is produced because of its high reactivity, ${ }^{2}$ and breakdown of this oxide layer is only known to happen in highly disruptive conditions, which does not often occur in the oral cavity. ${ }^{3,4}$ As such, Ti has been successfully used in medical devices, which includes dental and orthopedic implants. However, the Ti oxide layer does not allow for direct contact of the Ti and possible harmful metallic ions with the living host. ${ }^{1}$ Therefore, the Ti oxide layer allows 
for an implant to be accepted by host tissues, and eventually bone will grow around the implant.

\section{Hydroxyapatite}

Hydroxyapatite (HA) is another important material used for implants because it is very similar to calcium phosphate $(\mathrm{CaP})$ of teeth and bones. HA has an osteoconductive property that permits bone growth and direct bonding of bone to the implant surface. ${ }^{5-9}$ Previous evidence in a number of animal studies exemplified HA binding to bone. ${ }^{10-12}$ Studies showed that a gradual mineralization process occurs where there is bone healing around Ti implants, as opposed to bone-conducive healing. ${ }^{13,14}$ However, despite its excellent bone conductive property and biocompatibility, HA is a ceramic and is brittle in bulk form. In situations where load bearing implants are needed, such as in dental and orthopedic applications, the poor mechanical property of bulk HA thus renders the material useless for such applications. As a result, HA is a material of interest in early bone formation that has been used as a surface coating for $\mathrm{Ti}^{15}$

\section{Hydroxyapatite and Titanium}

The development of a HA coating is based on the reasoning of combining HA's bioactivity with Ti's strength. Combining HA with Ti has shown to form a strong bond between synthetic materials and bone. ${ }^{16-17}$ Furthermore, HA coatings have been reported to promote early bone formation around implants, and promote the deposition and differentiation of mesenchymal cells into osteoblasts on HA-coated implant surface. ${ }^{19}$ Ability of osteoblast adhesion onto the surface is due to the increased adsorption and 
production of proteins. In addition, a study has indicated HA-coated implants to have a higher percentage of bony contact after six weeks implantation as opposed to commercially pure Ti screws. ${ }^{20}$ Histologically comparing osseous apposition to HAcoated implants and Ti implants has demonstrated mineralization of bone directly on HA surfaces with no fibrous tissue layer formation. However, a predominately fibrous tissue interface was observed on Ti implants, with only minimal areas of direct bone contact. ${ }^{21}$ In addition, in an animal study HA-coated implants showed an increased coronal bone growth that was not observed with Ti implants. ${ }^{22}$ Maintaining a bony osseous crest is essential clinically because it may prevent peri-implant saucerization and subsequent pocket formation. ${ }^{23-24}$ Other histometric studies in animal models have also exemplified that bone adapts in much less time to HA-coated implants than to Ti implants. ${ }^{25-26}$

\section{Limitations}

However, there are limitations of HA and Ti in regards to healing and inflammation, and further investigations of antimicrobial materials are essential. Wounds can often influence an increase in a micro-organism population. This in turn, can affect the natural healing process and increase the rate of infection. There is a concern about enhanced susceptibility to bacterial colonization on HA-coated surfaces as compared to non-coated Ti implants. When implants are placed clinically, there are instances where bacteria can become a problem. Implant-associated infections account for nearly $50 \%$ of the estimated 2 million infections in the United States per year. ${ }^{27}$ Certain implants, like external fixation pins, have infection rates of up to $100 \%{ }^{28-30}$ There are high complication rates with these infections, which places a huge weight on patients, health 
care professionals, and the health care setting. A prolonged hospital stay, increased morbidity and mortality, and an increased financial load usually occurs to patients with infected implants. ${ }^{31}$ Bacteria on implant surfaces is known to cause inflammation around the implants which can decrease the implant's stability. For example, one study showed that the implantation of HA-coated implants had a higher intense inflammatory response as opposed to other implant materials. ${ }^{32}$ The HA coatings have been suggested to be more susceptible to bacterial colonization compared to Ti implants or natural teeth. ${ }^{33}$ As a result of the roughened HA surfaces, enhanced plaque growth on HA-coated implant surfaces is suggested, and therefore may contribute to peri-implantitis. ${ }^{34}$

\section{Silver}

One material known to have such antimicrobial effects is silver $(\mathrm{Ag})$. One in vivo study examined the antimicrobial efficacy and potential side-effects of a Ag-coated megaprosthesis. ${ }^{35}$ The Ag group showed significantly lower infection rates than the titanium group. In addition, there were no pathologic or histological changes evident. Ag has shown in a number of previous studies to have an antibacterial effect. ${ }^{36-38}$ As the $\mathrm{Ag}$ ion concentration was increased to $37^{\circ} \mathrm{C}$, an increase in the rate of bacteria killed was reported. ${ }^{36}$ Ag could decrease the rate of infection and decrease antimicrobial activity in dental implants. Ag is believed to be effective against a wide range of micro-organisms, and therapeutic effects are seen in low concentrations. ${ }^{39-40} \mathrm{Ag}$ is known to have antibacterial activity and a non-cytotoxic effect in stimulated body fluids. ${ }^{41}$ Furthermore, Ag can inhibit the growth of gram-positive and gram-negative bacteria. ${ }^{42}$ As a result of

Ag's antimicrobial effects, many medical devices such as catheters ${ }^{43-44}$ and wound 
dressings ${ }^{45}$ contain $\mathrm{Ag}$. In addition, the use of Ag-coated catheters in patients was shown to have reduced bacteria infection in comparison to non-coated catheters. ${ }^{46}$ The mentioned studies have provided strong evidence that $\mathrm{Ag}$ in medical implants can aid in reducing bacterial infection.

\section{Coating Processes}

Another problem with HA coatings is the current process that is used in the deposition, namely plasma-spraying process. It has been reported that plasma-sprayed HA exhibited variation in bond strength at the coating-metal interface, non-uniformity in coating thickness between vendors, alteration in structural and chemical properties, nonuniformity in coating density. ${ }^{47-56}$ In addition to these problems, plasma-spraying is a line-of-sight coating process and thus is not very useful in complex implant surfaces, such as beaded surfaces. As such, numerous experimental coating processes have been investigated, including electrophoretic deposition, high velocity oxy-fuel (HVOF) deposition, and radio frequency sputter deposition. ${ }^{56}$ Each of these experimental coating processes has resulted in improved coating properties, such as adhesion strength. However, one solution-based coating process known as the sol-gel technique is being proposed in this study. The sol-gel coating process is a low temperature deposition process that permits the operator to maintain control over the chemical composition and structure of the coating as well as coating on complex structures. ${ }^{57,58,59}$ In addition, the sol-gel procedure is economical as well as less time consuming. ${ }^{60}$ 


\section{Significance of Study}

In addition to the selection of a coating process to ensure successful implantation, the composition of the coatings are also critical for osseointegration. There have been studies examining surface modifications of implants and bone activity. However, none have studied the effects of Ag-doped HA coatings applied to dental implants on early bone response. It has never been determined whether Ag can affect bone remodeling as well as early onset of osseointegration. Therefore, Ti implants with coatings of Agdoped HA should be carefully examined in order to have a better understanding of bone response to various implant surfaces. Data generated from this study will provide important information on the effect of Ag-doped HA coatings on osteoblast response in vitro. In addition, this study will give useful information on the optimum surface treatment required for maximum implant stability and aid in providing a foundation for future in vivo and clinical studies with Ag. This essential information will contribute to the development of an ideal dental implant surface as well as reduce the number of implant failures. This, in turn, will minimize time, trauma, and implant and surgery costs for the patient.

\section{Aims and Hypotheses}

The overall purpose of this study was to investigate the biological response to Agdoped HA-coated Ti surfaces produced using a sol-gel deposition process. In this study, molecular and structural properties of the coatings were evaluated. In addition, the response of osteoblast cells as well as Staphylococcus aureus on Ag-doped HA coatings were evaluated. As such, the three specific aims for this study were the following: 
- Specific Aim 1: To characterize the coatings produced using the sol-gel coating process.

- Specific Aim 2: To determine attachment, differentiation, and mineralization of osteoblast cells on Ag-doped HA coatings.

- Specific Aim 3: To determine the attachment of bacteria on Ag-doped HA coatings.

In order to fulfill each of the above aims, the following hypotheses were tested:

- Hypothesis 1: No chemical and structural changes will be observed with the coatings produced using the sol-gel coating process.

- Hypothesis 2: Osteoblast attachment, differentiation, and mineralization will be affected by the doping of Ag on HA coatings.

- Hypothesis 3: Bacteria attachment on Ag-doped HA will be reduced when compared to HA coatings and Ti surfaces. 


\section{CHAPTER 2. METHODOLOGY}

\section{Titanium Substrates}

Commercially pure grade 2 Ti from Metal Samples, Munford, AL (14 mm diameter and $2 \mathrm{~mm}$ thick) was used in this study. The Ti surfaces were prepared by wet grinding with 240, 400 and 600 grit silicon carbide paper. Surface roughness measurement using Surtornic 3 profilometer (Taylor-Hobson, UK) indicated a $\mathrm{R}_{\mathrm{a}}$ value of $0.37 \pm 0.01 \mu \mathrm{m}$. These surfaces were ultrasonically degreased in acetone and ethanol for 10 minutes each, with deionized water rinsing between applications of each solvent. A passivation procedure was conducted by exposing the Ti samples to a $40 \%$ volume nitric acid solution at room temperature for 30 minutes (ASTM F86-76). After each surface treatment, the Ti samples were rinsed with deionized water and air-dried. After drying, these Ti samples were either used as controls, coated with HA or Ag-doped HA. All coated and non-coated samples were then UV sterilized for 24 hours prior to cell culture experiments.

\section{Coatings}

In this study, HA and 2\% Ag-doped HA sol were used as coatings on Ti implant surfaces. Silver nitrate $\left(\mathrm{AgNO}_{3}\right)$ was chosen as a precursor for silver because of the easy decomposition of nitrates during heating. $\mathrm{AgNO}_{3}$ was weighed so that $\mathrm{Ag}$ ion occupied $2.0 \%$ of all cations $(\mathrm{Ag}$ and $\mathrm{Ca}$ ) and dissolved with calcium nitrate tetrahydrate $\left[\mathrm{Ca}\left(\mathrm{NO}_{3}\right)_{2} \cdot 4 \mathrm{H}_{2} \mathrm{O}\right]$. The HA sol was prepared by reacting calcium nitrate tetrahydrate $\left[\mathrm{Ca}\left(\mathrm{NO}_{3}\right)_{2} \cdot 4 \mathrm{H}_{2} \mathrm{O}\right]\left(\right.$ Aldrich) with the triethyl phosphite $\left[\left(\mathrm{OC}_{2} \mathrm{H}_{5}\right)_{3} \mathrm{P}\right]($ Fluka $)$ in methyl 
alcohol using correct amounts to obtain the stoichiometric $\mathrm{Ca} / \mathrm{P}$ ratio of 1.67 for $\mathrm{HA}$. This was followed by the addition of $0.03 \mathrm{~mol}$ of $\mathrm{HCl}$ and $0.1 \mathrm{~mol}$ of DCCA (Drying Control Chemical Additive). All work was performed in argon atmosphere. The mixed solution was then aged at $80^{\circ} \mathrm{C}$ for 12 hours. The aged solution was filtrated through a 0.2 syringe filter, and aged again at $50^{\circ} \mathrm{C}$ for 7 days. After aging, $\mathrm{HA}$ or Ag-doped HA coatings was then spin-coated on Ti surfaces at $3500 \mathrm{rpm}$ for 30 seconds. The coated-Ti surfaces were immediately dried at $70^{\circ} \mathrm{C}$ for 12 hours and then heat-treated at $650^{\circ} \mathrm{C}$ for 3 hours. The HA without Ag doping was used as controls in this study. All samples were autoclaved prior to materials characterization and all culture experiment.

\section{Materials Characterization}

All coatings were characterized prior to beginning of study. In order to evaluate the structure of HA coatings, $\mathrm{x}$-ray diffraction was used. Triplicate coatings were analyzed using a x-ray diffractometer using $\mathrm{Cu} \mathrm{K}_{-}$radiation. $\mathrm{HA}$ coatings (without $\mathrm{Ag}$ doping) were used as controls. The energy used was $40 \mathrm{KeV}$ and $30 \mathrm{~mA}$. Data was collected from 5 degrees to 95 degrees two theta at 0.1 degree per minute scan rate. Peak reflections were identified by matching to the standard synthetic HA (JCPDS \# 9-0432).

\section{Osteoblast Cell Culture Study}

The osteoblast cell culture study was performed with the ATCC CRL 1486 human embryonic palatal mesenchyme cell line (HEPM), a precursor of osteoblast cells. The cells were suspended in Dulbecco's modified Eagle's medium (DMEM) containing 10\%

FBS, L-ascorbic acid, _-glycerophosphate, $2.5 \times 10^{-9} \mathrm{M} 1,25(\mathrm{OH})_{2}$ vitamin $\mathrm{D}_{3}$, and a $1 \%$ 
antibiotic/antimycotic mixture of penicillin, streptomycin and fungizone. Experiments were conducted in a $5 \% \mathrm{CO}_{2}$ humidified incubator at $37^{\circ} \mathrm{C}$, and the medium was changed twice a week. Sterilized HA (controls), Ti (controls), and Ag-doped HA surfaces were placed at the bottom of a well of 24-well plate. Samples were subsequently assayed for cell attachment, osteocalcin activity, and alkaline phosphatase activity. Details of the assays were as follows:

\section{Cell Attachment}

At 30,60,120, and 180 minutes after seeding, cells attached on each surface were evaluated. A $200 \mu \mathrm{l}$ cell suspension (44,000 cells) were seeded on each surface. At each time point, triplicate samples from each group were assayed by removing the media and washing the samples twice with PBS. The total volume of PBS used for each wash was $200 \mu 1$. The removed media and washed solution were saved and recorded as total volume. The number of unattached cells in the removed media and wash solution were subsequently determined using a Beckman Z2 Coulter Counter. Cells attached on each surface were then measured by subtracting the unattached cell concentration from the initial cell concentration seeded. Mean attachment cell concentrations between the different surfaces were statistically analyzed using the ANOVA, with the differences compared using the Tukey's procedure. The alpha level for data analysis will be set at 0.05 , and differences were considered significant if $\mathrm{P}<0.05$. 


\section{Alkaline Phosphatase Specific Activity}

Alkaline phosphatase (ALP) activity was quantified by rinsing (twice) the cells with PBS, followed by exposing the cells to $0.2 \%$ Triton-X-100 solution in order to permeabolize the cell membranes. The cells were then subjected to three freeze/thaw cycles, ultrasonically homogenizing the samples for 15 minutes, and centrifuging to remove large cellular debris. The resulting supernatant was assayed for the release of pnitrophenol from $\mathrm{p}$-nitrophenyl phosphate $(\mathrm{pH}=10.2)$ and its specific activity calculated. $50 \mu 1$ of each sample and standard was then pipetted into a 96-well plate and $50 \mu 1$ of pnitrophenyl phosphate substrate was added, followed by incubation in the dark at room temperature for 1 hour. After stopping the reaction using $50 \mu \mathrm{l}$ of $1 \mathrm{M} \mathrm{NaOH}$, and the absorbance was read at $405 \mathrm{~nm}$ using a microplate reader. ALP activity of cells from each surface was then calculated from prepared standards (Sigma, St. Louis, MO). Significant differences in ALP were statistically evaluated using ANOVA with Student Newman Kuels procedure as the post hoc test for evaluation of significant differences at $\mathrm{P}<0.05$.

\section{Osteocalcin Activity}

The production of osteocalcin in this study was measured using a commercially available Mid-Tac Human Osteocalcin EIA Kit (Stougton, MA). On the day of the assay, the samples were thawed at room temperature. The samples $(25 \mu 1)$ or human osteocalcin standard $(25 \mu \mathrm{l})$ were then added to microtiter plate provided with the kit. This was followed by the addition of osteocalcin antiserum $(100 \mu \mathrm{l})$ and allowed to incubate at $37^{\circ} \mathrm{C}$ for 2.5 hours. The solution was then aspirated and the plate was washed 3 times with $0.3 \mathrm{ml}$ of phosphate buffered saline. After washing, $100 \mu 1$ of Streptavidin- 
Horseradish Peroxidase reagent was added to all wells, gently mixed, and allowed to incubate at room temperature for 30 minutes. The medium was again gently aspirated and the plate washed 3 times with $0.3 \mathrm{ml}$ of phosphate buffer saline. $100 \mu 1$ of 3,3', 5,5' Tetramethylbenzidine and hydrogen peroxide solution (1:1) mixture was then added to all wells and incubated in the dark for 15 minutes. A sulfuric acid solution (100 $\mu 1)$ was added to all wells to stop the reaction. Absorbance was then immediately read at $450 \mathrm{~nm}$ using a microplate reader. Osteocalcin concentrations were determined from a standard curve using standards supplied with the kit. Significant differences in protein levels was statistically evaluated using ANOVA with Student Newman Kuels procedure as the post hoc test for evaluation of significant differences at $\mathrm{P}<0.05$.

\section{Bacteria Study}

In this study, an RP12 strain of Staphylococcus epidermidis (ATCC 35984) and the Cowan I strain of Staphylococcus aureus were used as model bacteria strain to evaluate the in vitro antimicrobial properties of Ag-doped HA coatings. The bacteria were grown overnight in Trypticase soy broth (TSB), washed in PBS, and adjusted to an

OD at $530 \mathrm{~nm}$ of $0.1 .2 \mathrm{ml}$ of the bacteria $\left(10^{7}\right.$ colony forming units (CFU)) per tube were added to $50 \mathrm{ml}$ sterilized tubes containing Ti (control), HA-coated (control), or Ag-doped HA-coated disks and were incubated at $37^{\circ} \mathrm{C}$ for 3 hours. Loosely attached cells were washed off by rinsing the disks with PBS. After rinsing, the disks were then put into a new tube containing $5 \mathrm{ml}$ of PBS, and were vigorously vortexed for 30 seconds. The numbers of CFU in the buffer were determined by plating dilutions on THB agar plates. 
Significant differences were statistically evaluated using ANOVA with Student Newman Kuels procedure as the post hoc test for evaluation of significant differences at $\mathrm{P}<0.05$. 


\section{CHAPTER 3. RESULTS}

\section{Materials Characterization}

X-ray diffraction pattern of AgHA coating is depicted in Figure 1. Peaks

attributable to HA were identified, indicating the transformation of amorphous to crystalline coatings following the post deposition heat treatment at $650{ }^{\circ} \mathrm{C}$ for 3 hour.

\section{Cell Attachment}

Figure 2 shows osteoblastic cell attachment to different surfaces after 30 minutes, 60 minutes, 120 minutes, and 180 minutes. After 180 minutes, there was a significantly less osteoblastic cell attachment seen with $2 \%$ Ag-doped HA, when compared to Ti and HA surfaces $(\mathrm{P}<0.05)$.
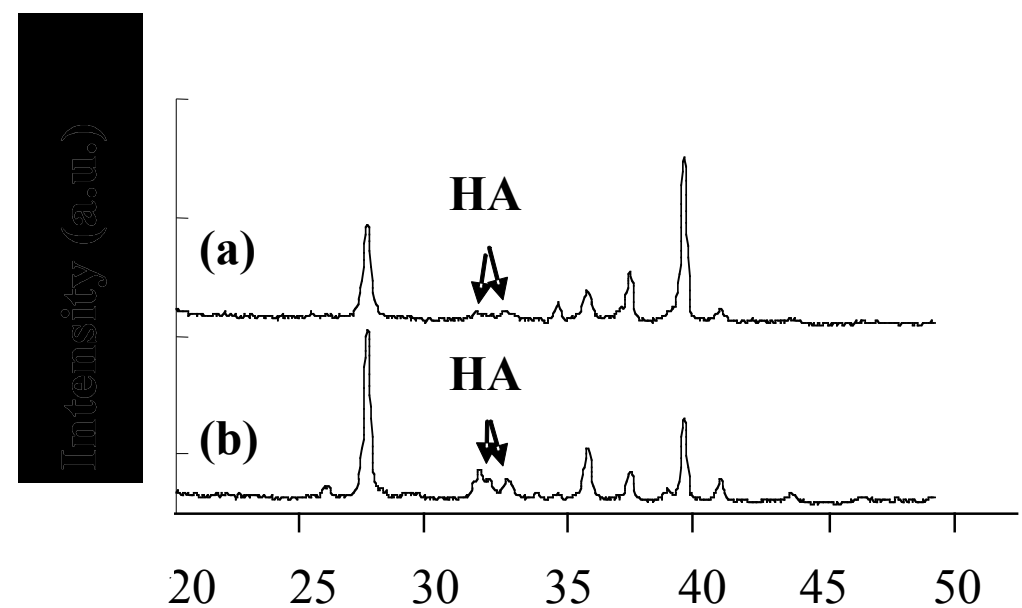

Figure 1. Characteristic x-ray diffraction pattern of (a) HA and (b) AgHA coatings, confirming the crystallinity of HA formed on the surfaces. HA peaks marked by the arrow indicate transformation due to heat treatment. 


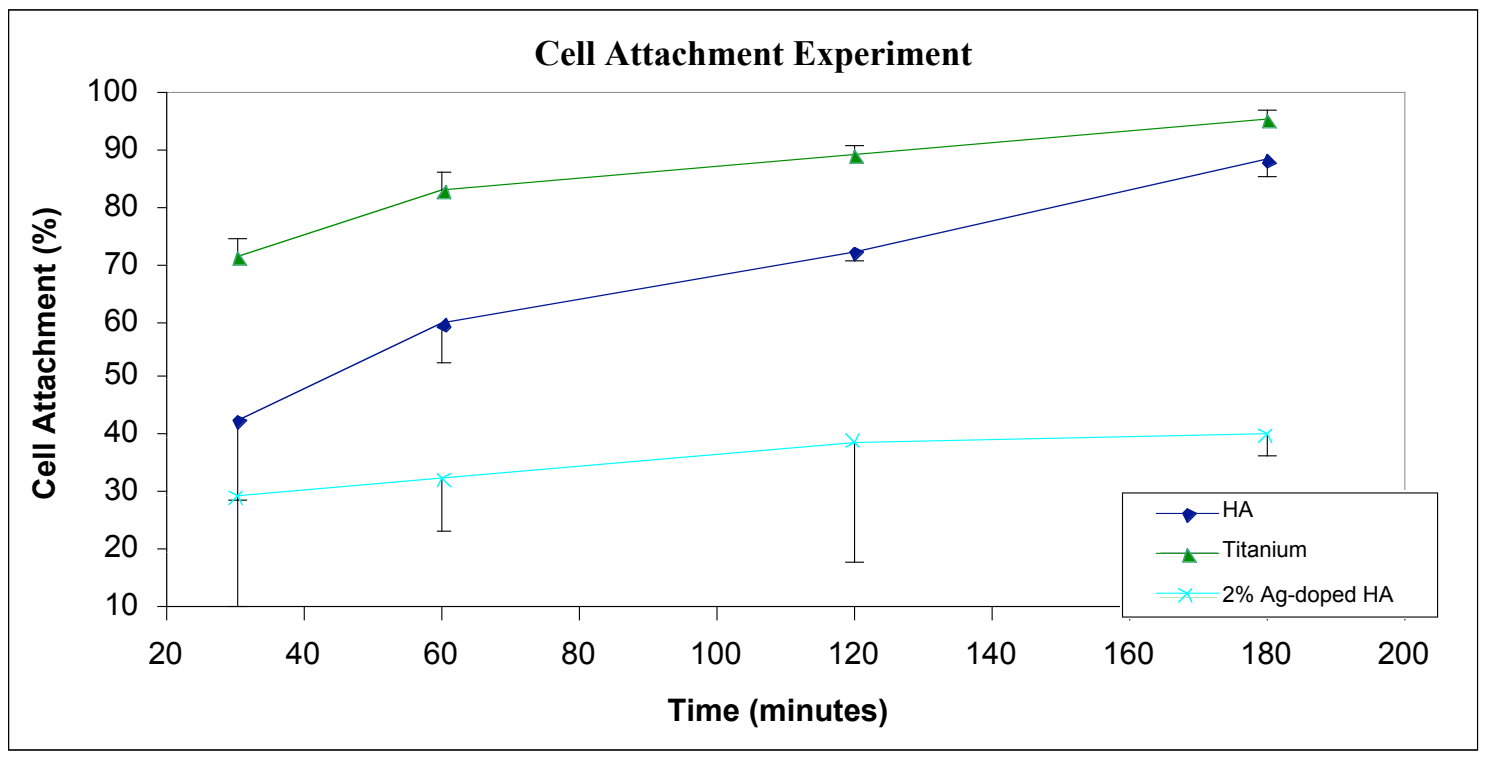

Figure 2. Osteoblastic cell attachment to different surfaces.

\section{Alkaline Phosphatase Specific Activity}

Figure 3 shows the ALP specific activity by osteoblast precursor cells on different surfaces after 3-day, 6-day, 9-day, and 12-day culture. By the 12th day, no significant difference with ALP specific activity was observed on Ag-doped HA surface when compared to Ti and HA surfaces $(\mathrm{P}>0.05)$.

\section{Osteocalcin Activity}

Figure 4 shows the osteocalcin activity by osteoblast precursor cells on different surfaces after 3-day, 6-day, 9-day, and 12-day culture. By the 12th day, no significant differences were found among the different surfaces $(\mathrm{P}>0.05)$. However, by the $12^{\text {th }}$ day Ti had the highest osteocalcin activity, when compared to HA and Ag-doped HA. 


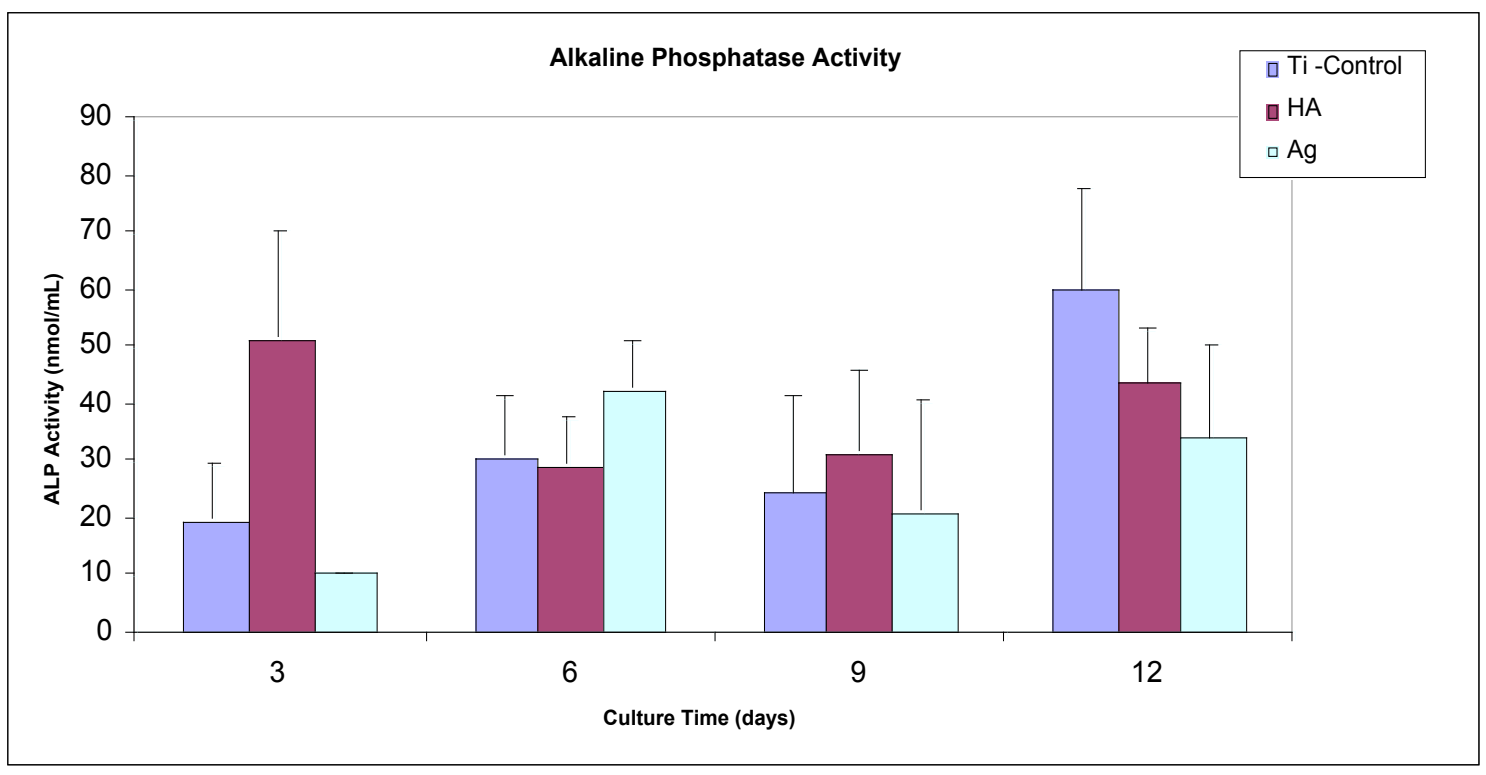

Figure 3. Alkaline phosphatase activity on different surfaces.

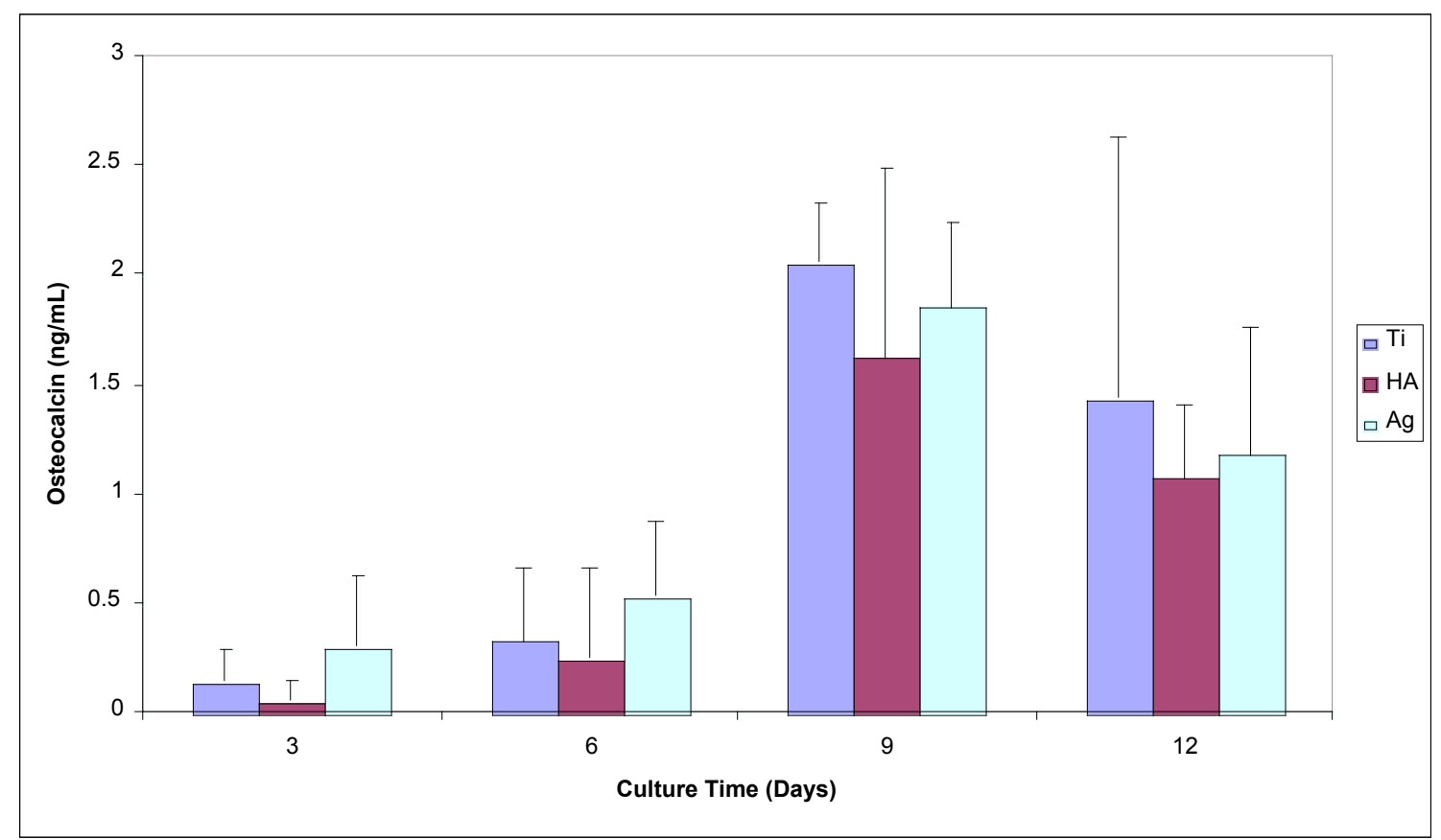

Figure 4. Osteocalcin activity on different surfaces. 


\section{Bacteria Study}

Figure 5 shows the results of viable bacteria adhering to the different surfaces when exposed to S. aureus. Bacterial adhesion was significantly reduced for S. aureus on Ag-doped HA surfaces when compared to HA and Ti surfaces $(\mathrm{P}<0.05)$.

Figure 6 also shows the results of viable bacteria adhering to the different surfaces when exposed to S. epidermidis. Bacterial adhesion was also significantly reduced for S. epidermidis on Ag-doped HA surfaces when compared to HA and Ti surfaces $(\mathrm{P}<0.05)$.

Overall, the Ag-doped HA surface was significantly better in reducing bacterial adhesion for both S. aureus and S. epidermidis, as compared to the HA and Ti surfaces.

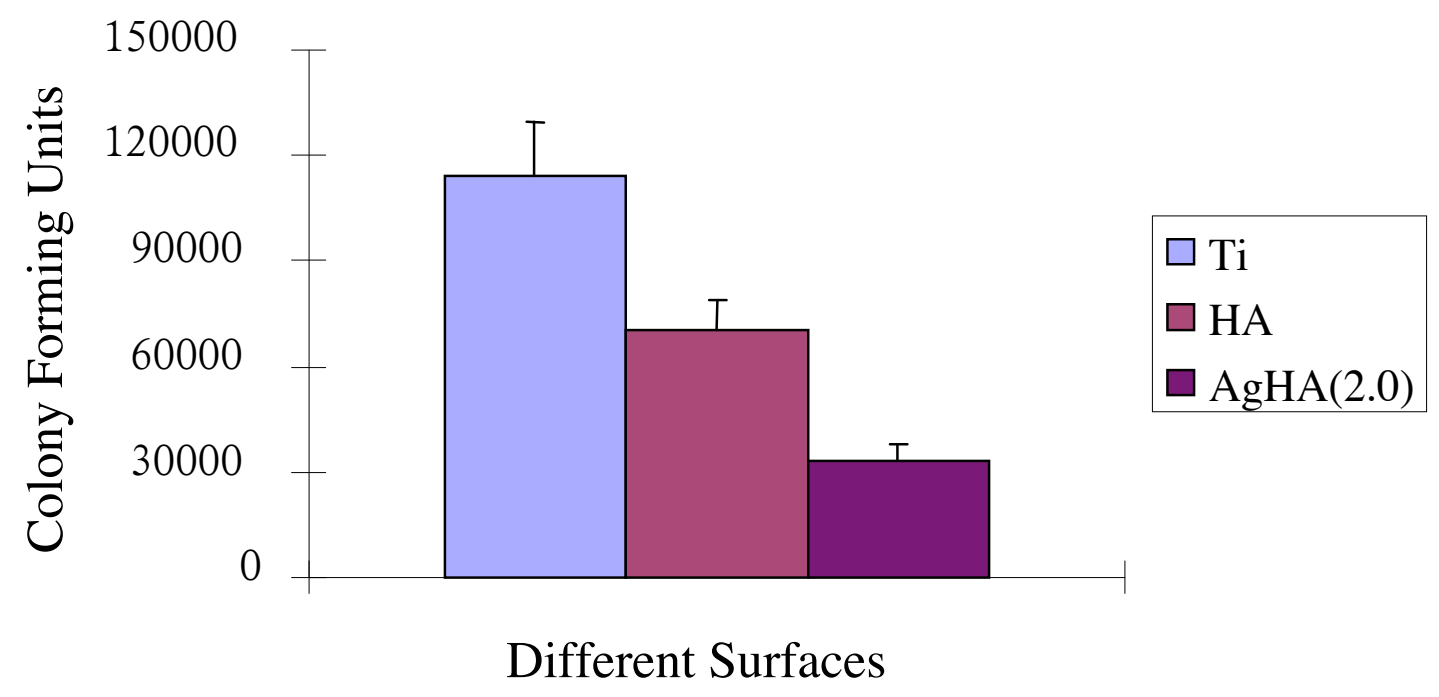

Figure 5. Attachment of S. aureus to different surfaces. 


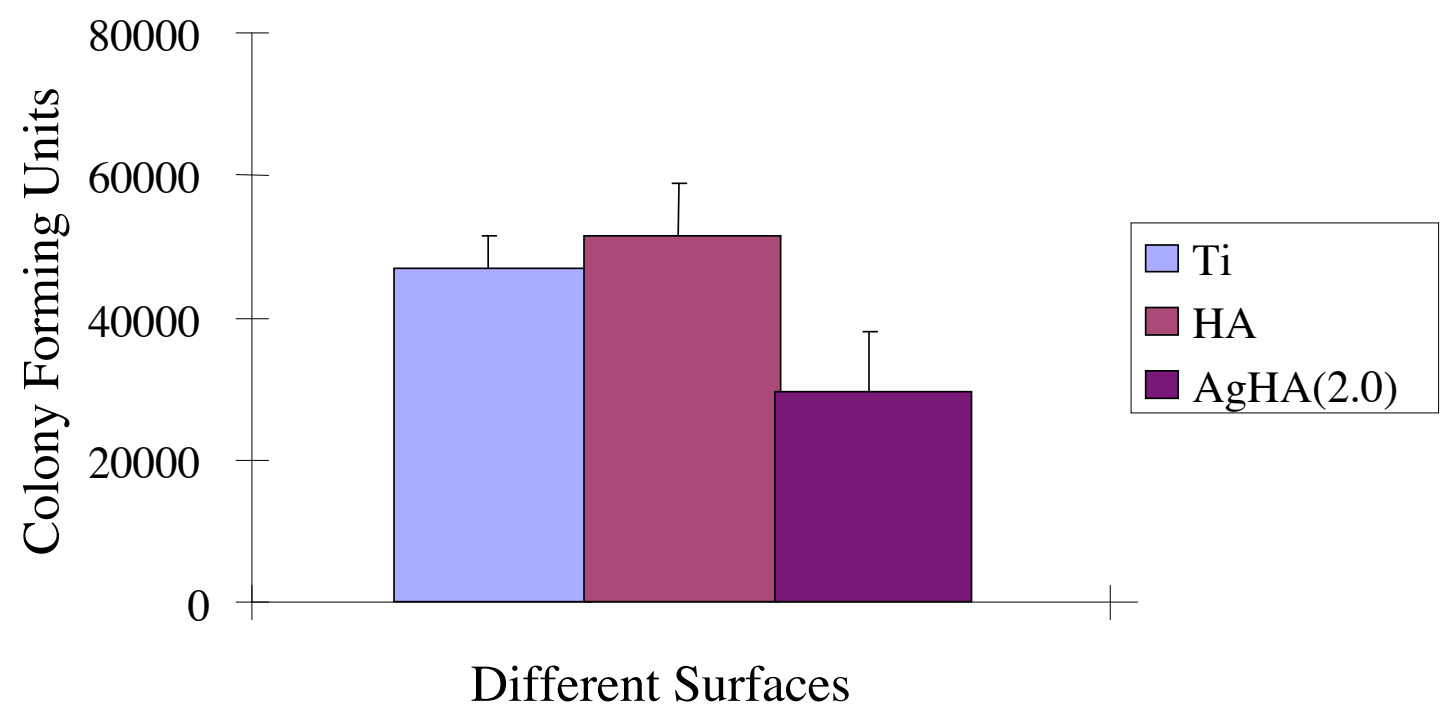

Figure 6. Attachment of S. epidermidis to different surfaces. 


\section{CHAPTER 4. DISCUSSION}

\section{Overview}

Ti has been widely used as implant materials because of their highly biocompatible properties with relatively low modulus, good fatigue strength, formability, machinability, and corrosion resistance. ${ }^{61-64}$ In addition, HA has been added to Ti surfaces as a coating material on orthopedic and dental implants. Adding HA to Ti has allowed combining the strength of the metals with the bioactivity of the ceramics. HA has helped promote more rapid osseointegration; this includes direct bony growth and early mineralization at the interface, as well as equivalent or higher bone implant bond strengths and percentage bone contact at the bone-implant interface compared to uncoated Ti implants. ${ }^{60,65-67}$

Furthermore, the sol-gel process has shown to be an economical and time-saving process. $^{60}$ The sol-gel procedure allows for control of composition and coating thickness as well as the ability to coat large or complex surfaces. ${ }^{57-59}$ In addition, the water-based sol-gel technique producing HA coating was shown to be dense and have a high bonding strength (37-44 MPa) between the coating and substrate. ${ }^{57,68,69}$

Bacterial infection and inflammation at the site of implant placement may impede healing of the soft and hard tissues, therefore eventually leading to chronic periimplantitis which has been reported to be one of the major etiological agents causing late implant failures. ${ }^{70,71}$ Due to this insight, a biomaterial that has enough strength and bioactivity, as well as anti-bacterial properties is worth investigating. One such material that has these mentioned properties is Ag. An important feature of Ag is its wide spectrum of antibacterial susceptibility and low incidence of resistance. ${ }^{72,73}$ 
It was hypothesized that HA thin film doped with Ag would not only enhance tissue compatibility, but also promote the inhibition of bacterial adhesion on the implant surface. In this study, characterization of Ag-doped HA film prepared using water-based sol gel technique was produced.

As observed in the x-ray diffraction analysis of the coatings, no Ag peaks were observed. The lack of Ag peaks from x-ray diffraction analysis was attributed to the low concentration of Ag used in the coatings. As expected, all HA and Ag doped HA peaks matched standard synthetic HA (JCPDS \# 9-0432), indicating the presence of HA coatings.

Additionally, the effect of Ag-doped HA was also evaluated using the human embryonic palatal mesenchyme cells (HEPM), an osteoblast precursor cell line. Osteoblastic cell attachment with 2\% Ag-doped HA was significantly less when compared to Ti and HA surfaces. However, this suggested that cell attachment for $2 \%$ Ag-doped HA was observed even if it was significantly less. It was also observed that the Ti surfaces had significantly more osteoblastic cell attachment than the HA surfaces. It is possible that the Calcium and Phosphorous released from the sol-gel coating on the HA surfaces impeded cell attachment. One study suggested that additional Phosphorous concentration in the cell culture media was suggested to slow down osteoblast differentiation and mineralization and affect HA dissolution behavior. ${ }^{74}$

It was observed that there was no significant difference on differentiation and mineralization of osteoblast precursor cells on 2\% Ag-doped HA surface when compared to the HA and Ti surfaces. This suggested that the osteoconductivity of AgHA was not 
reduced even though 2\% Ag-doped HA surface had less osseous activity than the HA and Ti surfaces.

Significant differences on the results of bacterial adhesion studies on Ti, HA, and Ag-doped HA surfaces were observed. The Ag-doped HA surface was observed to significantly reduce the number of viable adhering bacteria of tested strains which

included S. aureus and S. epidermidis. This suggested that the HA coating doped with 2\% Ag has an anti-bactericidal adhesion effect. Attachment of bacteria to implanted biomaterial surfaces is an important step in the pathogenesis of infection. Therefore, it is essential to eliminate as many infectious bacteria as possible. This work demonstrated that the Ag-doped HA coatings play an important role in preventing or minimizing initial bacterial adhesion.

\section{Future Research}

Future studies on Ag-doped HA surfaces will involve the long and short-term animal studies to evaluate its biocompatibility and its ability to induce bone formation for implant stability as well as bacterial adhesion properties. Furthermore, a change in the concentration for Ag may aid in an increased osteogenic activity as well as have an antimicrobial effect. For example, $1 \%$ or $0.5 \% \mathrm{Ag}$ may be used in future studies.

\section{Conclusion}

In this study, a significant difference in osteoblastic cell attachment over time was observed with $2 \%$ Ag-doped HA having the least cell attachment. In addition, no 
significant differences of the ALP specific activity or osteocalcin activity were observed over time, although there was less activity for $2 \% \mathrm{Ag}$-doped HA. Changing the composition affected cell responses, which can explain the reason for the lower attachment levels, ALP and osteocalcin activity. However, the Ag doping did not entirely prevent osteoblast cells from attaching and differentiating. Furthermore, the in vitro bacterial adhesion study indicated a significantly reduced number of S. epidermidis and S. aureus on 2\% Ag-doped HA surfaces when compared to HA and Ti surfaces. . Overall, it was concluded that $2 \% \mathrm{Ag}$-doped HA surfaces have similar osteoconductive activity when compared to HA and Ti surfaces. In addition, it was also concluded that the doping of HA with Ag minimized and prevented the adhesion of bacteria on its surfaces. 


\section{LIST OF REFERENCES}

1. Branemark PI. Tissue-integrated prostheses: Osseointegration in clinical dentistry. In Introduction to Osseointegration. Branemark PI, Zarb GA, Albrektsson T, Eds.; Quintessence; Chicago, 1985.

2. Albrektsson T, Branemark PI, Hansson HA, Ivarsson B, and Johsson U. Ultrastructural. In Clinical Applications of Biomaterials. Lee AJC, Albrektsson T, and Branemark PI, Eds.; Wiley; Chichester, 1982; 167-177.

3. Sennerby L, Thomsen P, Ericson LE. Ultrastructure of the bone-titanium interface in rabbits. Mater Med 1992; 3:262-271.

4. Seflik DE, Sik AL, Parr GR et al. Osteogenesis at the dental implant interface: High-voltage electron microscopic and conventional transmission electron microscopic observation. J Biomed Mater Res 1993; 27:791-800.

5. Hench LL and Andersson O. Bioactive glasses. In An Introduction to Bioceramics. Advance Series in Ceramics. Vol 1. Hench LL and Wilson J, Eds.; World Scientific; London, 1993; 41-73.

6. Hench LL and Wilson J. Surface active materials. Biomater Sci 1984; 226:630636.

7. Hench LL, Splinter RJ, Allen WC, and Greenlee TK. Bonding mechanisms at the interface of ceramics prosthetics materials. J Biomed Mater Res 1971; 2:117-141.

8. Osborn JF and Newesely H. The material science of calcium phosphate ceramics. Biomaterials 1980; 1:108-111. 
9. Muller-Mai CM, Stupp SI, Voigt C, Gross U. Nanoapatite and organoapatite implants in bone: Histology and ultrastructure of the interface. J Biomed Mater Res 1995; 29:9-18.

10. Suchanek W, Yoskimua M. Processing and properties of hydroxyapatite-based biomaterials for use as hard tissue replacement implants. J Mater Res 1998; 12:94-117.

11. Fartash B, Liao H, Li J, Founda N, Hermansson L. Long-term evaluation of titania-based ceramics compared with commercially pure titanium in vivo. $\mathrm{J}$ Master Sci Mater Med 1995; 6:451-454.

12. Daculsi G, Legeros RZ, Heughebaert M, Barbieux I. Formation of carbonateapatite crystals after implantation of calcium phosphate ceramics. Calcif Tissue Int 1990; 46:20-27.

13. Kokubo T. Bioactive glass ceramics: Properties and applications. Biomaterials $1991 ; 12: 155-163$.

14. Nie X, Leyland A, Matthews A. Deposition of layered bioceramic hydroxyapatite $/ \mathrm{TiO}_{2}$ coatings on titanium alloys using a hybrid technique of micro-arc oxidation and electrophoresis. Surface and Coatings Technology 2000; $125: 407-414$

15. Hamdi M, Ektessabi AM. Electron beam deposition of thin bioceramic film for biomedical implants. Thin Solid Films 2001; 398:385-390.

16. Cui FZ, Luo ZS, Feng QL. Highly adhesive hydroxyapatite coating on titanium alloy formed by ion beam assisted deposition. J Master Sci Mater Med 1997; 8: 403-405. 
17. Ong JL, Lucas LC, Prince CW, Raikar GN. Characterization of ion beam sputter deposited calcium phosphatate coating. In Encyclopedic handbook of biomaterials and bioengineering, Part A: Material. Wise Dl, Trantolo DJ, Altobelli DE, Yaszemski MJ, Gresser JD, Schwartz ER, Eds.; Marcel Dekker, Inc; New York, 1995; 1565-1581.

18. Wang CK, Chern LJH, Ong JCP HC, Chang RPH. Structural characterization of pulsed laser deposited hydroxyapatite film on titanium substrate. Biomaterials. 1997; 18:1331-1338.

19. Cleries L, Martinez E, Fernandez-Pradas JM et al. Mechanical properties of calcium phosphate coatings deposited by laser ablation. Biomaterials. 2000; 21: 967-971.

20. Gottlander M, Albrektsson T, Carlsson LV. Histomorphometric studies of hydroxyapatite-coated and uncoated CP titanium threaded implants in bone. Inter J Oral Maxillofac Implants 1992; 7:485-490.

21. Thomas KA, Kay JF, Cook SD, Jarcho M. The effect of surface macrotexture and hydroxyapatite coating on the mechanical strength and histologic profiles of titanium implant material. J Biomed Mater Res 1987; 21:1395-1414.

22. Gammage DD, Bowman AE, Meffert RM, Cassingham RJ, Davenport WA. A histologic and scanning electron micrographic comparison of the osseous interface in loaded IMZ and Integral implants. Inter J Periodont Rest Dent 1990; 10:125-135. 
23. Kohri M, Cooper EP, Ferracane JL, Waite DF. Comparative study of hydroxyapatite and titanium dental implants in dogs. J Oral Maxillofac Surg 1990; 48:1265-1273.

24. Pilliar RM, Deporter DA, Watson PA, Paroah M, Chipman M, Valiquette N. The effect of partial coating with hydroxyapatite on bone remodeling in relation to porous-coated titanium-alloy dental implants in the dog. J Dent Res 1991; 70:1338-1345.

25. Gottlander M and Albrektsson T. Histomorphometric studies of hydroxyapatitecoated and uncoated CP titanium threaded implants in bone. Inter J Oral Maxillofac Implants 1991; 6:399-404.

26. Weimlaender M, Kennedy EB, Lekovic V, Beumer J, Moy PK, Lewis S. Histomorphometry of bone apposition around three types of endosseous dental implants. Inter J Oral Maxillofac Implants 1992; 7:491-496.

27. Schierholz JM and Beuth J. Implant infections: A haven for opportunistic bacteria. J Hosp Infect 2001; 49:87-93.

28. Green SA. Complications of external skeletal fixation. Clin Ortho Rel Res 1983; 180:109-116.

29. Ahlborg HG and Josefsson PO. Pin-tract complications in external fixation of fractures of the distal radius. Acta Orthop Scand 1999; 70:116-118.

30. Garberina MJ, Fitch RD, Hoffmann ED, Hardaker WT, Vail TP, Scully SP. Knee arthrodesis with circular external fixation. Clin Ortho Rel Res 2001; 382:168-78.

31. Hebert CK, Williams RE, Levy RS, Barrack RL. Cost of treating an infected total knee replacement. Clin Ortho Rel Res 1996; 331:140-145. 
32. Gabrielli MAC, Marcantonio Jr. E, Goissis G, Okamoto T, Gabrielli MFR, Vieira RH. Hydroxyapatite implants with or without collagen in the zygomatic arch of rats. Histological study. Braz Dent J 2001; 121:9-15.

33. Rams TE, Roberts TW, Feik D, Molzan AK, Slots J. Clinical and microbiological findings on newly inserted hydroxyapatite-coated and pure titanium human dental implants. Clin Oral Implants Res 1991; 2:121-127.

34. Rosenberg ES, Torosian JP, Slots J. Microbial differences in 2 clinically distinct types of failures of osseointegrated implants. Clin Oral Implants Res 1991; 2:135144.

35. Russell AD and Hugo WB. Antimicrobial activity and action of silver. Prog Med Chem 1994; 31:351-370.

36. MacKeen PC, Person S, Warner SC, Snipes W, Stevens SE. Silver-coated nylon fiber as an antibacterial agent. Antimicrob Agents Chemother 1987; 31:93-99.

37. Kawashita M, Tsuneyama S, Miyaji F, Kokubo T, Kozuka H, Yamamoto K. Antibacterial silver-containing silica glass prepared by sol-gel method. Biomaterials 2000; 21:393-398.

38. Kawashita M, Toda S, Kim HM, Kokubo T, Masuda N. Preparation of antibacterial silver-doped silica glass microspheres. J Biomed Mater Res A 2003; $66: 266-274$

39. Lansdown ABG, Sampson B, Laupattarakasem P, and Vuttiviorjan A. Silver aids healing in the sterile skin wound: Experimental studies in the laboratory rat. $\mathrm{Br} \mathrm{J}$ Dermatol 1997; 137:728-735. 
40. Gosheger G, Hardes J, Ahrens H, Streitburger A, Buerger H, Erren M, Gunsel A, Kemper FH, Winkemann W, Von Eiff C. Silver-coated megaendoprostheses in a rabbit model—An analysis of the infection rate and toxicological side effects.

Biomaterials. 2000; 25(24):5547-5556.

41. Verne E, Di Nunzio S, Bosetti M, Appendino P, Vital Brovarone C, Maina G, Cannas M. Surface characterization of silver-doped bioactive glass. Biomaterials $2005 ; 26: 5111-5119$.

42. Cho K-H, Park J-E, Osaka T, Park S-G. The study of antimicrobial activity and preservative effects of nanosilver ingredient. Electrochimica Acta. Article in Press, Corrected Proof; 2005.

43. Sampath LA, Chowdury N, Caraos L, Modak SM. Infection resistance of surface modified catheters with either short-lived or prolonged activity. J Hosp Infect $1995 ; 30: 201-210$.

44. Dasqupta MK. Silver peritoneal catheters reduce bacterial colonization. Adv Perit Dial 1994; 10:195-198.

45. Adams AP, Santschi EM, Mellencamp MA. Antibacterial properties of a silver chloride-coated nylon wound dressing. Vet Surg 1999; 28:219-225.

46. Saint S and Lipsky BA. Preventing catheter-related bacteruria: Should we? Can we? How? Arch Intern Med 1999; 159:800-808.

47. Lemons, JE. Hydroxyapatite coatings. Cling. Orthp. Rel. Res. 1988; 235:220223. 
48. Lacefieled, WR. Hydroxylapatite Coatings. In Bioceramics: Material Characteristics versus in vivo Behavior. Ducheyne, P; Lemons, JE, Eds.; The New York Academy of Science; New York, 1988; 72-80.

49. Ducheyne P, Cuckler JM. Bioactive ceramic prosthetic coatings. Clin Orthop Rel Res 1992; 276:102-114.

50. Furlong RJ, Osborn JF. Fixation of hip prostheses by hydroxyapatite ceramic coatings. J Bone Joint Surg 1991; 73B:741-745.

51. Geesink RGT. Osteoconductive coating for total joint arthroplasty. Clin Orthop Rel Res 2002; 395:53-65.

52. Havelin LI, Engesaeter LB, Espehaug B, Furnes O, Lie SA, Vollset, SE. The Norwegian arthroplasty register, 11 years and 73,000 arthroplasties, Acta Orthop Scand 2000; 71:337-353.

53. D’Antonio JA, Capello WN, Manley MT, Geessink R. Hyroxyapatite femoral stems for total hip arthroplasty. Clin Orthop Rel Res 2001; 393:101-111.

54. de Groot K, Wolke JGC, Jansen JA. State of the art: Hydroxyapatite coatings for dental implants. J Oral Implantology. 1994; 20:232-234.

55. Yang, Y, Ong JL, Bessho K. Plasma-sprayed hydroxyapatite-coated and plasmasprayed titanium-coated implants. In Biomaterials in Orthopedics. Yaszemski, MJ, Trantolo DJ, Lewandrowski, K, Hasirci V, Altobelli DE, Wise, DL., Eds., Marcel Dekker, Inc; New York, 2004; 401-423.

56. Yang Y, Kim KH, Ong JL. A review on calcium phosphate coating produced using a sputtering process- An alternative to plasma spraying. Biomaterials. 2005; 26:32-337. 
57. Kim HW, Kim HE, Salih V, Knowles JC. Hydroxyapatite and titania sol-gel composite coatings on titanium for hard tissue implants: Mechanical and in vitro biological performance. J Biomed Mater Res B Appl Biomater 2005; $72: 1-8$.

58. Gross KA, Chai CS, Kannangara GS, Ben-Nissan B, Hanley L. Thin hydroxyapatite coatings via sol-gel synthesis. J Mater Sci MaterMed 1998; 9: 839-843.

59. Liu DM, Yang Q, Troczynski T, Tseng WJ. Structural evolution of sol-gelderived hydroxyapatite. Biomaterials 2002; 23:1679-1687.

60. Chung RJ, Hsieh MF, Huang CW, Perng LH, Wen HW, Chin TS. Antimicrobial effects and human gingival biocompatibility of hydroxyapatite sol-gel coatings. J Biomed Mater Res B Appl Biomater 2006; 76:169-178.

61. Yang Y, Oh N, Liu Y, Chen W, Oh S, Appleford M, Kim S, Kim K, Park S, 2. Bumgardner J, Haggard W, Ong J. Enhancing osseointegration using surfacemodified titanium implants. J OralMaxillofac Surg 2006; 58:67-69.

62. Breme J, Steinhauser E, Paulus G. Commercially pure titanium Steinhauser platescrew system for maxillofacial surgery. Biomaterials. 1988; 9:310-313.

63. Browne M, Greqson PJ. Effect of mechanical surface pretreatment on metal ion release. Biomaterials 2000; 21:385-392.

64. Niinomi M. Fatigue performance and cyto-toxicity of low rigidity titanium alloy, Ti-29Nb-13Ta-4.6Zr. Biomaterials 2003; 24:2673-2683. 
65. Ong JL, Bessho K, Carnes DL. Bone response to plasma-sprayed hydroxyapatite and radiofrequency-sputtered calcium phosphate implants in vivo. Int J Oral Maxillofac Implants 2002; 17:581-586.

66. Yang Y, Kim K, Ong JL. A review on calcium phosphate coatings produced using a sputtering process-An alternative to plasma spraying. Biomaterials 2005; 26 : $327-337$.

67. McPherson EJ, Dorr LD, Gruen TA, Saberi MT. Hydroxyapatite coated proximal ingrowth femoral stems. A matched pair control study. Clin Orthop Relat Res $1995 ; 315: 223-230$.

68. Liu DM, Troczynski T, Tseng WJ. Water-based sol-gel synthesis of hydroxyapatite: Process development. Biomaterials 2001; 22:1721-1730.

69. Liu DM, Yang Q, Troczynski T. Sol-gel hydroxyapatite coatings on stainless steel substrates. Biomaterials 2002; 23:691-698.

70. Esposito M, Hirsch JM, Lekholm U, Thomsen P. Biological factors contributing to failures of osseointegrated oral implants. II. Etiopathogenesis. Eur J Oral Sci $1998 ; 106: 721-764$.

71. Flemming T, Renvert S.Consensus report: Maintenance and complications. In Proceeding of the 3rd European Workshop on Peridontology. Lang NP, Karring T, Lindhe J, Eds.; Quintessence; Berlin, 1999; 347-351.

72. Kramer SJ, Spadaro JA, Webster DA. Antibacterial and osteoinductive properties of demineralized bone matrix treated with silver. Clin Orthop Relat Res 1981; 161:154-162. 
73. Gristina AG. Biomaterial-centered infection: Microbial adhesion versus tissue integration. Science 1987; 237:1588-1595.

74. Ma S, Yang Y, Carnes DL, Kim K, Park S, Oh SH, Ong JL. Effects of Dissolved Calcium and Phosphorous on Osteoblast Responses. Journal of Oral Implantology 2005; 31.2:61-67. 


\section{VITA}

Nicole Frances Besu was born in Ceiba, Puerto Rico on June 26, 1977. Her family moved to Miami, Florida in 1980. She graduated from Our Lady of Lourdes Academy High School in May of 1995. Nicole received a Bachelor of Science degree in Psychology from The University of Michigan in Ann Arbor in 1999. In May of 2004 she graduated from Nova Southeastern University College of Dental Medicine in Fort Lauderdale, Florida with a Doctor of Dental Medicine degree. In July of 2004, Dr. Besu entered The University of Tennessee's Health Science Center Periodontology residency program. She is expected to receive a Master of Dental Science degree in May 2007. Following graduation, she will begin her career as a practicing Periodontist. 